\title{
Pulsed Fe Electro-Oxidation for Catalytic Synthesis of Hydantoin Derivatives
}

\author{
S. Santiago-Ruiz ${ }^{1}$, L.J. Torres-Pacheco ${ }^{2}$, M.T. Oropeza-Guzman ${ }^{2, *}$, I. A. Rivero ${ }^{1, *}$ \\ ${ }^{1}$ Centro de Graduados e Investigación en Química, Tecnológico Nacional de México, Instituto \\ Tecnológico de Tijuana, C.P. 22500 Tijuana, B. C., Mexico \\ ${ }^{2}$ Centro de Investigacion y Desarrollo Tecnológico en Electroquímica, subsede Tijuana, Carretera \\ Tijuana-Tecate km 26.5, Parque Industrial El Florido, C.P. 22444, Tijuana, B. C. México \\ "E-mail: irivero@ tectijuana.mx, moropeza@ cideteq.mx
}

doi: $10.20964 / 2016.07 .13$

Received: 21 January 2016 / Accepted: 15 April 2016 / Published: 4 June 2016

This paper presents an original and practical organic electrochemical/chemical (EC/C) synthesis to prepare hydantoin derivatives from N-Alkyl-piperidin-4-ones. The electrochemical assisted process is an alternative to the traditional Bucherer-Bergs method. The main contribution is the in-situ production of $\mathrm{Fe}$ (III), by pulsed electro-oxidation of an iron wire, in a methanol-water (1:1) mixture at $58^{\circ} \mathrm{C}$. The oxidized iron, on the wire surface, served as catalyst in the traditional synthetic path of hydantoin derivatives, and the $\mathrm{KCN}$ and $\left(\mathrm{NH}_{4}\right)_{2} \mathrm{CO}_{3}$ aided as supporting electrolyte for the electrolytic process. EC/C prepared hydantoins were characterized by IR, NMR $\left({ }^{1} \mathrm{H},{ }^{13} \mathrm{C}\right)$, and MS. The pulsed potential applied to the iron wire was $0.9 \mathrm{~V} / \mathrm{Ag} / \mathrm{AgCl} / \mathrm{Cl}^{-}$sat $\mathrm{KCl}(\mathrm{MeOH})$ during $300 \mathrm{~s}$, alternated with $-0.1 \mathrm{~V}$ $/ \mathrm{Ag} / \mathrm{AgCl} / \mathrm{Cl}^{-}$sat $\mathrm{KCl}(\mathrm{MeOH})$ during $60 \mathrm{~s}$. The electrode potential program attempted to avoid electrode surface passivation. After identifying the produced hydantoins by a thin-layer chromatography, electric charge corresponding to the current integration during the pulses of $300 \mathrm{~s}$ (10 cycles) gave a total oxidation charge density of $5.57 \mathrm{C} / \mathrm{cm}^{2}$ for hydantoin 8-(3-nitrobenzyl(-1,3,8-triazaespyrodecane-2,4dione) and $2.68 \mathrm{C} / \mathrm{cm}^{2}$ for 8-(4-nitrobenzyl(-1,3,8-triazaespyrodecane-2,4-dione),. The EC/C synthesis was compared with the traditional Bucherer-Berg method, resulting in an increase of 12-fold more hydantoins in $60 \mathrm{~min}$.

Keywords: hydantoins, N-piperidone, $\mathrm{Fe}$ electro-oxidation in metanol-water, organic electrochemical/chemical synthesis.

\section{FULL TEXT}

(C) 2016 The Authors. Published by ESG (www.electrochemsci.org). This article is an open access article distributed under the terms and conditions of the Creative Commons Attribution license (http://creativecommons.org/licenses/by/4.0/). 